\title{
PENGARUH PENDEKATAN MATEMATIKA REALISTIK (PMR) TERHADAP KEMAMPUAN PEMECAHAN MASALAH MATEMATIKA SISWA
}

\author{
Suriyani \\ STKIP Labuhanbatu,JIn. SM. Raja No. 126A, KM, 3.5 Aek Tapa, Rantauprapat \\ Email:suryani.jahwa@yahoo.com \\ Diterima (Oktober 2018) dan disetujui (Nopember 2018
}

\begin{abstract}
Abstrak
Tujuan penelitian ini adalah untuk mengetahui pengaruh Pendekatan Matematika Realistik (PMR) terhadap kemampuan pemecahan masalah matematika siswa pada pokok bahasan Sistem Persamaan Linear Dua Variabel (SPLDV). Penelitian dilaksanakan di SMP Negeri 1 Pulau Rakyat Kabupaten Asahan. Jenis penelitian kuantitatif dengan metode yang digunakan yaitu metode kuasi eksperimen dan desain penelitian yang digunakan yaitu One-Group Pretest-Posttest Design. Sampel dalam penelitian ini adalah siswa kelas $\mathrm{VIII}^{1}$ yang berjumlah 31 siswa. Instrumen yang digunakan adalah instrumen tes dengan tipe uraian sebanyak 3 soal. Data diperoleh dari hasil tes yang diberikan kepada siswa berupa soal pretest yang diberikan sebelum proses pembelajaran dan posttest yang diberikan diakhir proses pembelajaran. Analisis data menggunakan uji Paired Samples T-Test, berdasarkan analisis data tersebut diperoleh thitung $=13,154>$ tabel $=1,697$ dan nilai Sig. (2-tailed) sebesar $0,000<0,05$ maka $\mathrm{H}_{0}$ ditolak dan $\mathrm{H}_{\mathrm{a}}$ diterima. Hal ini menunjukkan bahwa terdapat pengaruh Pendekatan Matematika Realistik (PMR) terhadap kemampuan pemecahan masalah matematika siswa pada materi Sistem Persamaan Linear Dua Variabel (SPLDV).
\end{abstract}

\section{Kata Kunci : Pendekatan Matematika Realistik, Kemampuan Pemecahan Masalah}

\section{PENDAHULUAN}

Matematika merupakan bagian dari ilmu pengetahuan yang memiliki peranan penting dalam pembentukan kualitas sumberdaya manusia. Mutu pendidikan matematika harus terus ditingkatkan sebagai upaya pembentukan sumber daya manusia yang bermutu tinggi, yakni manusia yang mampu berfikir kritis, logis, sistematis, kreatif, inovatif, dan berinisiatif dalam menanggapi masalah yang terjadi. Menurut Subryanto (2014: 121) matematika memiliki peran penting dalam berbagai disiplin ilmu dan memajukan daya pikir manusia sehingga diajarkan pada semua jenjang pendidikan mulai dari sekolah dasar sampai perguruan tinggi.

Namun, kenyataannya pendidikan di Indonesia mengalami permasalahan. Salah satu masalahnya adalah lemahnya proses pembelajaran, terutama pada jenjang SMP. Hal ini ditandai dengan rendahnya prestasi belajar matematika siswa yang dilansir dari
Kemdikbud tahun 2011 menyatakan bahwa menurut survei internasional PISA (Programme for International Student Assessment) rata-rata skor prestasi literasi matematika Indonesia masih berada di bawah rata-rata international. Selain survei PISA, Laporan TIMSS (The Third International Mathematics Science Study) menunjukkan bahwa kemampuan siswa kelas dua SMP (eighth grade) Indonesia relatif lebih baik dalam menyelesaikan soal-soal tentang fakta dan prosedur, akan tetapi sangat lemah dalam menyelesaikan soal- soal non rutin yang berkaitan dengan jastifikasi atau pembuktian, pemecahan masalah yang memerlukan penalaran matematis, menemukan generalisasi dan menemukan hubungan antara data-data atau fakta yang diberikan (Syaiful, 2012:37). Konsekuensinya jika mereka diberikan soal non rutin mereka akan membuat kesalahan (Kesumawati, 2009:485). 
Berdasarkan kenyataan di atas, siswa akan membuat kesalahan jika diberikan soal non rutin. Itu berarti kemampuan pemecahan masalah siswa Indonesia masih kurang, padahal dalam pembelajaran matematika kemampuan pemecahan masalah sangat penting, sebagaimana dikemukakan oleh Branca (dalam Syaiful, 2012:37) menyatakan bahwa kemampuan pemecahan masalah merupakan tujuan umum pengajaran matematika, bahkan sebagai "jantung" dari matematika.

Meskipun pemecahan masalah menjadi "jantung" dari matematika, masih banyak siswa mengalami kesulitan dalam menyelesaikan soal yang berkaitan dengan pemecahan masalah. Berdasarkan hasil wawancara dengan Ibu Zubaidah, S.Pd selaku guru mata pelajaran matematika di SMP Negeri 1 Pulau Rakyat Kabupaten Asahan pada hari kamis 13 April 2017, diperoleh informasi bahwa sebagian besar siswa terutama dikelas VIII menganggap matematika itu pelajaran yang sulit dipahami, sehingga siswa kurang berminat belajar matematika, siswa sering melamun disaat belajar matematika, siswa sering mengantuk, siswa tidak mau bertanya jika ada hal yang kurang dimengerti siswa, siswa juga cenderung kurang mampu dalam menggunakan rumus/konsep yang diperlukan dalam pemecahan masalah, hal itu mengakibatkan rendahnya kemampuan siswa dalam memecahkan masalah. Bukan hanya itu, siswa juga kurang mampu menyelesaikan soal cerita atau soal non rutin. Hal tersebut sesuai dengan pendapat Usman (dalam Subryanto, 2014:121) pada umumnya soal cerita dalam matematika sulit untuk diselesaikan .

Kesulitan yang dialami siswa dalam menyelesaikan soal cerita, kemungkinan faktor yang pertama adalah pendekatan yang digunakan dalam proses pembelajaran kurang membangun kemampuan pemecahan masalah matematis. Guru masih menggunakan pendekatan konvensional dengan metode ceramah. Ini sesuai dari pendapat Suwarsono (dalam Kesumawati, 2009:487) secara umum proses belajar mengajar matematika di sekolah-sekolah di Indonesia terpusat pada guru yaitu guru menjelaskan, siswa mendengarkan sambil mencatat, guru bertanya, murid menjawab, siswa mengerjakan soal-soal latihan. Faktor kedua adalah siswa kurang memperhatikan langkah-langkah dalam menyelesaikan suatu permasalahan yang ada di soal. Untuk menyelesaikan suatu permasalahan yang ada di soal akan lebih mudah jika dikerjakan dengan menggunakan langkah-langkah yaitu memahami masalah, merencanakan penyelesaian, menyelesaikan masalah sesuai rencana, dan melakukan pengecekan kembali terhadap semua langkah yang telah dikerjakan (Polya dalam Fitriana, 2010:32).

Berdasarkan hal tersebut, maka diperlukan suatu alternatif pembelajaran yang dapat membantu meningkatkan kemampuan siswa dalam menyelesaikan soal-soal non rutin atau soal yang banyak mengasah kemampuan pemecahan masalah khususnya pada materi SPLDV. Salah satu alternatif pembelajaran yang dapat digunakan adalah pendekatan Pembelajaran Matematika Realistik (PMR).

Menurut Zulkardi (dalam Subryanto,

2014:122):

Pembelajaran Matematika Realistik (PMR) merupakan pendekatan yang bertitik tolak dari hal-hal yang nyata bagi siswa, menekankan keterampilan proces of doing mathematics, berdiskusi dan berkolaborasi, beragumentasi dengan teman sekelas sehingga mereka dapat menemukan sendiri konsep matematika dan pada akhirnya dapat menggunakan matematika untuk menyelesaikan masalah, baik secara individu maupun kelompok.

Tujuan dari PMR sendiri adalah memberikan kesempatan kepada siswa untuk menemukan kembali dan merekonstruksi konsep-konsep matematika dengan mengaitkannya dalam dunia nyata serta mampu untuk memecahkan masalah yang mungkin mereka jumpai dalam kehidupan nyata, dengan demikian penggunaan PMR dalam proses pembelajaran sesuai untuk membantu meningkatkan kemampuan siswa dalam memecahkan masalah.

Berdasarkan hal tersebut, rumusan masalah dalam penelitian ini adalah: (1) Apakah terdapat pengaruh Pendekatan Matematika Realistik (PMR) terhadap kemampuan pemecahan masalah matematika siswa pada materi Sistem Persamaan Linear Dua Variabel (SPLDV) ? (2) Bagaimanakah proses jawaban siswa dengan Pendekatan Matematika Realistik (PMR) terhadap kemampuan pemecahan masalah matematika siswa pada materi Sistem Persamaan Linear Dua Variabel (SPLDV)?

\section{METODOLOGI PENELITIAN}

Penelitian ini menggunakan jenis penelitian Kuantitatif dengan metode yang digunakan yaitu metode kuasi eksperimen dan desain penelitian yang digunakan yaitu One- 
Group Pretest-Posttest Design. Rancangan ini terdapat pre-test dan post-test. Sebelum diberikan perlakuan, maka terlebih dahulu diberikan pre-test. Selanjutnya diberikan perlakuan dengan menggunakan Pendekatan Matematika Realistik (PMR), setelah diberikan perlakuan kemudian diberikan post-test.
Dengan demikian hasil perlakuan dapat diketahui lebih akurat, karena dapat membandingkan dengan keadaan sebelum diberi perlakuan (Sugiyono, 2008:74). Untuk lebih jelasnya desain penelitian dapat dilihat pada tabel berikut :

Tabel 3.1 : One-Group Pretest-Posttest Design

\begin{tabular}{|c|c|c|c|}
\hline Kelompok & $\begin{array}{c}\text { Tes Awal } \\
\text { (Pre-test) }\end{array}$ & Perlakuan & $\begin{array}{c}\text { Tes Akhir } \\
\text { (Post-test) }\end{array}$ \\
\hline Eksperimen & $\mathrm{O}_{1}$ & $\mathrm{X}$ & $\mathrm{O}_{2}$ \\
\hline
\end{tabular}

Keterangan:

$\mathrm{O}_{1} \quad$ :Pre-test (tes awal sebelum proses belajar mengajar dimulai dan belum diberikan perlakuan)

$\mathrm{O}_{2}$ : Post-test (tes akhir setelah proses belajar mengajar berlangsung dan sudah diberikan perlakuan)

$X$ :Perlakuan peneliti dengan menggunakan Pendekatan Matematika Realistik (PMR)

Penelitian ini dilaksanakan di SMP Negeri 1 Pulau Rakyat Kabupaten Asahan. Penelitian dilaksanakan pada semester ganjil tahun ajaran 2017/2018 pada bulan Juli dengan populasi seluruh kelas VIII berjumlah 93 siswa, yang terbagi dalam 3 kelas yaitu $\mathrm{VIII}^{1}$, VIII ${ }^{2}$, dan $\mathrm{VIII}^{3}$. Namun, yang menjadi sampel penelitian adalah kelas VIII ${ }^{1}$ dengan 31 siswa.

Adapun instrumen penelitiannya adalah instrumen tes yang berupa uraian sebanyak 6 butir soal. Instrumen tes tersebut terlebih dahulu diujicobakan untuk mengetahui validitas, reliabilitas, indeks kesukaran dan daya pembeda. Setelah diujicobakan,

diperoleh 3 butir soal yang layak digunakan dalam penelitian. 3 butir soal tersebut diberikan sebelum pembelajaran (pre-test) dan sesudah pembelajaran (post-test).

Untuk selanjutnya pengelolaan data diawali dengan menghitung uji prasyarat yaitu uji normalitas dan uji homogenitas, kemudian dilakukan uji-t untuk menguji hipotesis yang disesuaikan dengan perumusan masalah.

\section{HASIL DAN PEMBAHASAN}

Pengelompokan hasil dengan kategori yang telah ditetapkan dapat dilihat pada tabel 4.1 berikut ini :

Tabel 4.1 Pengelompokan Skor Kemampuan Pemecahan Masalah Matematika Siswa

\begin{tabular}{|c|l|}
\hline Kategori & \multicolumn{1}{|c|}{ Kriteria } \\
\hline Tinggi & Siswa yang memiliki nilai dengan interval 27 -39 \\
\hline Sedang & Siswa yang memiliki nilai dengan interval $14-26$ \\
\hline Rendah & Siswa yang memiliki nilai dengan interval 1-13 \\
\hline
\end{tabular}

a. Deskripsi Hasil Pretest

Berdasarkan tabel pengelompokan diatas, distribusi frekuensi hasil pretest dengan jumlah siswa 31 orang terlihat pada tabel 4.2 berikut:

Tabel 4.2 Distribusi Frekuensi Hasil Pretest

\begin{tabular}{|c|c|c|}
\hline No. & Interval Nilai & Frekuensi \\
\hline 1 & $27-39$ & 2 \\
\hline 2 & $14-26$ & 13 \\
\hline 3 & $1-13$ & 16 \\
\hline \multicolumn{2}{|c|}{ Jumlah } & 31 siswa \\
\hline
\end{tabular}


Dari tabel 4.2 diatas, dapat diketahui bahwa siswa yang memiliki kategori tinggi sebanyak 2 siswa, yang memiliki kategori sedang sebanyak 13 orang siswa dan yang memiliki kategori rendah sebanyak 16 orang siswa.

\section{b. Deskripsi Hasil Posttest}

Setelah diberi perlakuan dengan menggunakan Pendekatan Matematika Realistik (PMR) pada pokok bahasan Sistem Persamaan Linear Dua Variabel (SPLDV), dilakukan tes akhir (Posttest). Distribusi frekuensi hasil posttest kemampuan pemecahan masalah matematika siswa dapat dilihat pada tabel 4.3 berikut ini :

Tabel 4.3 Distribusi Frekuensi Hasil Posttest

\begin{tabular}{|c|c|c|}
\hline No. & Interval Nilai & Frekuensi \\
\hline 1 & $27-39$ & 12 \\
\hline 2 & $14-26$ & 17 \\
\hline 3 & $1-13$ & 2 \\
\hline \multicolumn{2}{|r|}{ Jumlah } & 31 siswa \\
\hline
\end{tabular}

Dari tabel 4.3 diatas, dapat diketahui bahwa siswa yang memiliki kategori tinggi sebanyak 12 siswa, yang memiliki kategori sedang sebanyak 17 orang siswa dan yang memiliki kategori rendah sebanyak 2 orang siswa.

\section{c. Perbandingan Hasil Pretest dan Posttest}

Perbandingan hasil pretest dan posttest kemampuan pemecahan masalah matematika siswa kelas VIII ${ }^{1}$ SMP Negeri 2 Na.IX-X Sumberjo dapat dilihat pada tabel 4.4 berikut ini :

Tabel 4.4 Perbandingan Hasil Pretest dan Posttest Kemampuan Pemecahan Masalah Matematika Siswa

\begin{tabular}{|c|c|c|c|c|}
\hline \multirow{2}{*}{ No. } & \multirow{2}{*}{ Kategori } & \multirow{2}{*}{ Interval Nilai } & \multicolumn{2}{|c|}{ Frekuensi } \\
\cline { 4 - 5 } & Tinggi & $27-39$ & Pretest & Posttest \\
\hline 2 & Sedang & $14-26$ & 13 & 12 \\
\hline 3 & Rendah & $1-13$ & 16 & 2 \\
\hline \multicolumn{2}{|r|}{ Jumlah } & 31 siswa & 31 siswa \\
\hline
\end{tabular}

Dari tabel perbandingan diatas, dapat dilihat adanya perubahan antara frekuensi pretest dan posttest. Lebih jelasnya lihat diagram batang perbandingan hasil pretest dan posttest dibawah ini : 


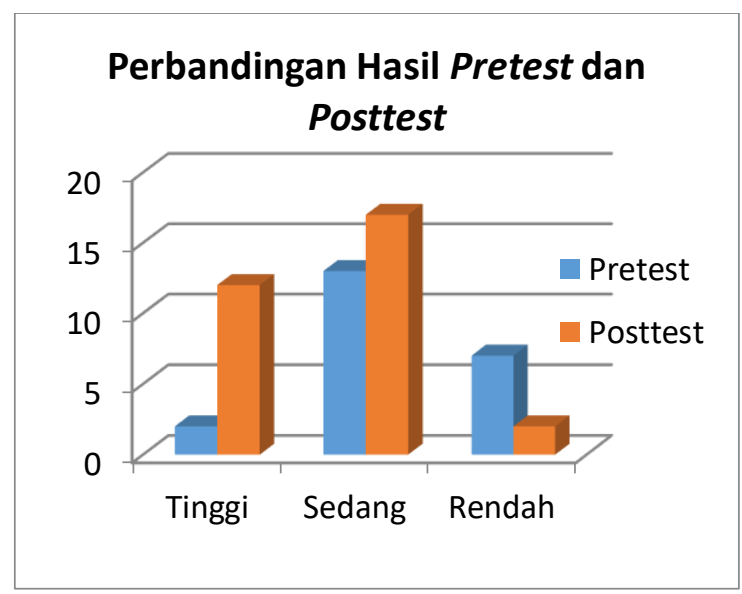

Gambar 4.1.

\section{Perbandingan Hasil Pretest dan Posttest}

Dari grafik diatas, sebelum diberikan perlakuan, siswa yang memiliki kategori tinggi hanya 2 orang, namun setelah diberi perlakuan siswa yang memiliki kategori tinggi menjadi 12 orang. Untuk kategori sedang, sebelum diberi perlakuaada 13 orang dan setelah diberi perlakuan ada 17 orang. Kemudian sebelum diberikan perlakuan, siswa yang memiliki kategori rendah sebanyak 16 orang, namun setelah diberikan perlakuan siswa yang memiliki kategori rendah hanya 2 orang. Terlihat jelas bahwa perlakuan (treatment) tersebut mempengaruhi hasil yang siswa peroleh.

Secara deskriptif, proses jawaban siswa dapat dianalisis dengan melihat hasil pekerjaan siswa pada masing-masing butir soal. Berdasarkan hasil pekerjaan siswa pada soal 1 diatas, siswa dikatakan mampu memahami masalah, siswa juga merencanakan penyelesaian masalah dengan membuat permisalan dan membuat model matematika serta menentukan cara yang akan digunakan untuk menyelesaikan masalah, siswa mampu melaksanakan penyelesaian masalah dengan menjawab permasalahan pada soal bahwa uang Andi tidak cukup untuk membeli satu buah apel dan satu buah mangga. Namun, pada tahap ini siswa tidak menuliskan bagaimana cara siswa memeriksa kembali jawaban yang telah diperoleh.

Berdasarkan hasil pekerjaan siswa pada soal 2 diatas, terlihat bahwa siswa mampu memahami masalah, siswa juga mampu merencanakan penyelesaian masalah dengan membuat permisalan dan membuat model matematikanya serta menentukan cara apa yang akan digunakan untuk menyelesaikan masalah, siswa mampu melaksanakan penyelesaian masalah dengan berhasil menjawab permasalahan pada soal dengan tepat bahwa harga $1 \mathrm{~kg}$ gula adalah $\mathrm{Rp}$.
$12.500,00$ dan harga $1 \mathrm{~kg}$ tepung adalah Rp. $5.000,00$. Tetapi, pada tahap akhir siswa tidak mampu menuliskan bagaimana cara siswa memeriksa kembali jawaban yang telah diperoleh.

Berdasarkan hasil pekerjaan siswa pada soal 3 diatas, terlihat bahwa siswa mampu memahami masalah ditandai dengan menuliskan diketahui dan ditanyakan dari soal dengan benar, siswa juga merencanakan penyelesaian masalah dengan membuat permisalan dan membuat model matematika serta menentukan cara apa yang akan digunakan untuk menyelesaikan masalah, kemudian siswa mampu melaksanakan penyelesaian masalah dengan menjawab permasalahan pada soal bahwa harga semua jambu mete bu Indah sebesar Rp. 232.000,00. Namun, pada tahap akhir siswa tidak dapat menuliskan bagaimana cara siswa memeriksa kembali jawaban yang telah diperoleh.

Dari keseluruhan proses jawaban siswa diatas, terlihat bahwa setelah diberikan perlakuan (treatment) proses jawaban siswa rata-rata mampu memahami masalah, merencanakan penyelesaian masalah, melaksanakan penyelesaian masalah. Namun sulit untuk melakukan pemeriksaan kembali. Hal tersebut dikarenakan siswa merasa yakin bahwa jawaban mereka sudah benar atau siswa lupa memeriksa jawabannya. Walaupun demikian, banyak siswa yang menjawab dengan hasil benar dan tuntas, hanya beberapa orang siswa yang menjawab salah.

Untuk menguji apakah perlakuan (treatment) pada sampel memberikan hasil yang berbeda secara nyata atau tidak, maka digunakan statistik parametrik dengan uji Paired Samples T-Test. Berikut adalah tabel hasil uji hipotesis data pretest dan posttest menggunakan uji Paired Samples T-Test: 
Tabel 4.5 Hasil Uji Hipotesis Paired Samples T-Test

Data Pretest dan Posttest

\begin{tabular}{|c|c|c|}
\hline $\mathbf{t}$ & Sig. ( 2 - tailed) & Keputusan \\
\hline 13,154 & 0,000 & $\mathrm{H}_{\mathrm{a}}$ diterima \\
\hline
\end{tabular}

Berdasarkan tabel 4.5 diatas, terlihat bahwa thitung $=13,154>t_{\text {tabel }}=1,697$, dan nilai Sig.(2-tailed) sebesar 0,000 $<0,05$, maka $\mathrm{H}_{\mathrm{a}}$ diterima dan dapat disimpulkan bahwa terdapat pengaruh yang signifikan antara Pendekatan Matematika Realistik (PMR) terhadap kemampuan pemecahan masalah matematika siswa pada materi Sistem Persamaan Linear Dua Variabel (SPLDV).

Selain dilihat dari uji hipotesis, pengaruh kemampuan pemecahan masalah matematika siswa juga dapat dilihat dari skor yang diperoleh siswa. Pada soal pretest skor siswa dengan kategori tinggi hanya 2 orang, sedangkan pada soal posttest skor siswa dengan kategori tinggi sebanyak 12 orang. Untuk skor kategori rendah pada soal pretest sebanyak 16 orang dan pada soal posttest hanya 2 orang siswa.

Oleh karena itu, setelah diberi perlakuan terdapat peningkatan atau dengan kata lain skor posttest lebih tinggi dibandingkan skor pretest. Berarti Pendekatan Matematika Realistik (PMR) mempengaruhi kemampuan pemecahan masalah matematika siswa. Dengan demikian penelitian "pengaruh Pendekatan Matematika Realistik (PMR) terhadap kemampuan pemecahan masalah matematika siswa pada materi Sistem Persamaan Linear Dua Variabel (SPLDV)" mampu menjawab hipotesis yang diajukan melalui analisis data-data yang diperoleh yaitu penelitian membuktikan bahwa terdapat pengaruh Pendekatan Matematika Realistik (PMR) terhadap kemampuan pemecahan masalah matematika siswa.

\section{KESIMPULAN}

Berdasarkan hasil pengolahan dan analisis data yang diperoleh dari penelitian yang telah dilakukan di SMP Negeri 1 Pulau Rakyat Kabupaten Asahan yang berlokasi di desa sei raja, dusun sumberjo, kecamatan $\mathrm{Na}$. IX-X, kabupaten labuhanbatu utara, maka dapat ditarik kesimpulan sebagai berikut :
1. Terdapat pengaruh Pendekatan

Matematika Realistik (PMR) terhadap kemampuan pemecahan masalah matematika siswa pada materi Sistem Persamaan Linear Dua Variabel (SPLDV). Hal ini dapat dibuktikan dari skor yang diperoleh siswa, pada soal pretest skor siswa dengan kategori tinggi hanya 2 orang, sedangkan pada soal posttest skor siswa dengan kategori tinggi sebanyak 12 orang. Untuk skor kategori rendah pada soal pretest sebanyak 16 orang dan pada soal posttest hanya 2 orang siswa. Demikian juga berdasarkan uji Paired Samples T-Test diperoleh thitung $=13,154>$ tabel $=1,697$ dan nilai Sig. (2-tailed) sebesar 0,000<0,05, maka $\mathrm{H}_{0}$ ditolak dan $\mathrm{H}_{\mathrm{a}}$ diterima.

2. Setelah diberikan perlakuan (treatment) proses jawaban siswa rata-rata mampu memahami masalah, merencanakan penyelesaian masalah, melaksanakan penyelesaian masalah namun sulit untuk melakukan pemeriksaan kembali. Walaupun demikian, banyak siswa yang menjawab dengan hasil benar dan tuntas, hanya beberapa orang siswa yang menjawab salah.

\section{SARAN}

Berdasarkan kesimpulan diatas, selanjutnya dapat diajukan beberapa saran yang dapat dijadikan pertimbangan, yaitu:

1. Guru hendaknya menanamkan pada siswa bahwa pembelajaran matematika bermakna dalam kehidupan sehari-hari, sehingga siswa sendiri akan mencari dan menyukai pelajaran matematika.

2. Siswa sebaiknya lebih banyak diberi kesempatan untuk mengkonstruksi sendiri dalam memecahkan masalah matematika dan presentasi hasil masalahnya.

3. Pembelajaran dengan Pendekatan Matematika Realistik (PMR) perlu terus diterapkan dan dikembangkan pada materi lain agar siswa lebih memahami materi yang dipelajari yaitu yang berhubungan dan berguna bagi kehidupan sehari-hari.

4. Sebagai bahan referensi bagi peneliti selanjutnya. Hendaknya peneliti selanjutnya lebih menjelaskan kepada siswa mengenai indikator-indikator pemecahana masalah, terutama indikator pada tahap akhir yaitu siswa mampu memeriksa kembali jawaban yang mereka peroleh. 


\section{DAFTAR PUSTAKA}

Subryanto, Muhammad. 2014. Implementasi Pendekatan Pembelajaran Matematika Realistik (PMR) untuk Meningkatkan Pemahaman Siswa terhadap Soal Cerita tentang Himpunan. Jurnal Pendidikan matematika Volume 3 Nomor 2. 12 April 2017

Syaiful. 2012. Peningkatan Kemampuan Pemecahan Masalah Matematis Melalui Pendekatan Pendidikan Matematika Realistik. Program Studi Pendidikan Matematika FPMIPA FKIP Universitas Jambi. Jurnal Pendidikan Volume 2 Nomor 1. Tersedia: dari http://eprints.uny.ac.id . 11 April 2017

Kemdikbud. 2011. Survei Internasional PISA. [Online]. Tersedia: http://litbang.kemdikbud.go.id/index.php/ survei-internasional-pisa [19 April 2017].

Kemdikbud. 2011. Survei Internasional TIMSS. [Online]. Tersedia: http://litbang.kemdikbud.go.id/index.php/ survei-internasional-timss $\quad[19$ April 2017].

Kesumawati, Nila. 2009. Peningkatan Kemampuan Pemecahan Masalah Matematis Siswa SMP Melalui Pendekatan Pendidikan Matematika Realistik. Program studi pendidikan matematika FKIP Universitas PGRI Palembang. Prosiding Seminar Nasional Matematika dan Pendidikan Matematika Jurusan Pendidikan Matematika. Tersedia: dari http://eprints.uny.ac.id. 11 April 2017

Fitriana, Hanny. 2010. Pengaruh Pendekatan Pendidikan Matematika Realistik terhadap Kemampuan Pemecahan Masalah Matematika Siswa. Program studi pendidikan matematika Fakultas IImu Tarbiah dan Keguruan UIN Syarif Hidayatullah Jakarta. 10 April 2017

Sugiyono. 2008. Metode Penelitian Kuantitatif, Kualitatif dan R\&D. Bandung : ALFABETA 